\title{
Evaluation of Simultaneous Saccharification and Fermentation of Oil Palm Empty Fruit Bunches for Xylitol Production
}

\author{
Khairul Hadi Burhan¹, Made Tri Ari Penia Kresnowati1,2,*, Tjandra Setiadi1,3 \\ ${ }^{1}$ Microbiology and Bioprocess Technology Laboratory, Department of Chemical Engineering, \\ Institut Teknologi Bandung, Indonesia \\ ${ }^{2}$ Department of Food Engineering, Institut Teknologi Bandung, Indonesia \\ ${ }^{3}$ Center for Environmental Studies (PSLH), Institut Teknologi Bandung, Bandung, Indonesia
}

Received: 28th November 2018; Revised: 21st May 2019; Accepted: 24th May 2019;

Available online: 30th September 2019; Published regularly: December 2019

\begin{abstract}
The biological process route of xylitol production from lignocellulosic materials, via enzymatic hydrolysis which is followed by fermentation, offers a more sustainable or greener process than the chemical process route. Both the enzymatic hydrolysis and the fermentation processes are conducted at moderate process condition and thus require less energy and chemicals. However, the process proceeds slower than the chemical one. In order to improve process performance, the enzymatic hydrolysis and the fermentation processes can be integrated as Simultaneous Saccharification and Fermentation (SSF) configuration. This paper discusses the evaluation of SSF configuration on xylitol production from Oil Palm Empty Fruit Bunches (OPEFB). To integrate two processes which have different optimum temperature, the performance of each process at various temperature was first evaluated. Later, SSF was evaluated at various hydrolysis and fermentation time at each optimum temperature. SSF showed better process performance than the separated hydrolysis and fermentation processes. The best result was obtained from configuration with 72 hours of prior hydrolysis followed by simultaneous hydrolysis and fermentation, giving yield of 0.08 g-xylitol/g-OPEFB. Copyright ( 2019 BCREC Group. All rights reserved
\end{abstract}

Keywords: Enzymatic hydrolysis; fermentation; OPEFB; process integration; xylitol

How to Cite: Burhan, K.H., Kresnowati, M.T.A.P., Setiadi, T. (2019). Evaluation of Simultaneous Saccharification and Fermentation of Oil Palm Empty Fruit Bunches for Xylitol Production. Bulletin of Chemical Reaction Engineering \& Catalysis, 14(3): 559-567 (doi:10.9767/bcrec.14.3.3754.559-567)

Permalink/DOI: https://doi.org/10.9767/bcrec.14.3.3754.559-567

\section{Introduction}

Xylitol is a five-carbon sugar alcohol that has comparable sweetening power to that of sucrose, and it can readily be digested in the human body without involving insulin. Xylitol cannot

* Corresponding Author.

E-mail: kresnowati@che.itb.ac.id (M.T.A.P. Kresnowati);

Telp: +62-22-2500989, Fax: +62-22-2501438 be consumed by oral bacteria which makes it tooth friendly. The absence of the carbonyl group in xylitol makes it cannot undergo the Maillard-reaction. Xylitol also has a negative heat of solution thus can give a 'cooling sensation'. These characteristics make xylitol favourable for food and pharmaceutical industries [14].

Xylitol is derived from xylose, which is generally available in its polymeric form, xylan, in 
the hemicellulose portions of plant cell walls. Several hydrolysis methods of lignocellulosic biomass to obtain xylose have been explored, i.e. mechanical, thermal combination, chemical, and enzymatic methods [5-7]. The dilute-acidcatalysed hydrolysis has been thoroughly explored [8-10]. However, its application requires a specific construction material that can withstand harsh operating conditions. The alkalinecatalysed hydrolysis has also been proposed [11-13]. These processes may also require plenty of chemicals for $\mathrm{pH}$ adjustment for the following process. As an alternative, enzymatic hydrolysis has also been suggested [14-16]. Although it is relatively slow, the process can be carried out at a moderate operation condition.

Xylose conversion to xylitol can be conducted via chemical hydrogenation by using noble metal catalysts $[17,18]$. This method requires high purity xylose as the reactant $[4,19,20]$. Alternately, the conversion can be performed by utilising biological agents including bacteria, filamentous fungi, yeasts, and enzymes. In the early studies, Parajo' [21] investigated xylitol production from Eucalyptus globulus wood hydrolysate, by utilising $D$. hansenii NRRL Y7426, giving final xylitol concentration of 8 $\mathrm{g} / \mathrm{L}$ and xylitol yield of $0.79 \mathrm{~g} x y l i t o l / g$ xylose or about $0.11 \mathrm{~g}$ xylitol/g wood. Recently, xylitol production was observed by utilising Candida guilliermondii FTI 20037 [22,23] to produce $\mathrm{xy}$ litol from bagasse hydrolysate with the yield as much as $0.63 \mathrm{~g}$ xylitol/g xylose consumed or about $0.14 \mathrm{~g}$ xylitol/g sugarcane bagasse. The typical fermentation process, the microbial conversion of xylose to xylitol, may take hours or days to proceed $[3,24,25]$. To make this process applicable in industrial scale, the process has to be rapid, provides the high yield, and utilises agricultural waste as alternative cheaper culture media [26].

One of the abundant resources available in Indonesia is Oil Palm Empty Fruit Bunches (OPEFB), with the amount of 34 million tonnes are produced annually as biomass residue from oil palm industries [27]. They are used neither as animal feed because of the rough texture nor as fuel because of high water content [28]. The biomass is composed of cellulose (34-43\%), xylan-rich hemicellulose (23-35\%), and lignin (1123\%) [1] therefore, it provides good raw material for xylitol production. The utilisation of OPEFB for xylitol production will give an added value for the oil palm industry and aiding pollution abatement.

The utilisation of OPEFB for xylitol production had been initiated in 2004 giving the highest yield of $0.67 \mathrm{~g} / \mathrm{g}$-xylose from charcoalthreated hydrolysate using $D$. hansenii [29]. Further study revealed the optimum condition for C. tropicalis giving the highest yield of 0.84 g/g-xylose [30]. Another research investigated the effect of glucose in xylitol production then provided the highest yield of $0.24 \mathrm{~g} / \mathrm{g}$-xylose on the optimum glucose to xylose ratio at 0.25 (w/w) by using $D$. hansenii [31].

To improve the efficiency of the biological route of xylitol production, it is proposed to integrate the enzymatic hydrolysis process of lignocellulosic material (saccharification) and the microbial conversion of the hydrolysate to xylitol (fermentation). The process is thus called simultaneous saccharification and fermentation (SSF). By simultaneous saccharification and fermentation (SSF), enzymatic hydrolysis can be carried out simultaneously with the fermentation in one process [32]. This process offers several advantages, including continuous removal of hydrolysis end-products that inhibits enzyme activity and short processing time [33].

This method had first been introduced for ethanol production [34,35]. Saha [36] investigated the comparison between separated hydrolysis and fermentation and simultaneous hydrolysis and fermentation for ethanol production using engineered Escherichia coli strain FBR5 utilising wheat straw. The obtained results showed that the ethanol yield from the lignocellulosic material (g ethanol/g straw) of the simultaneous process was $16 \%$ higher than the yield obtained from the one conducted separately. In addition, the total time course of the integration process was 40 hours shorter than the one conducted separately. Another research showed that the application of SSF on wheat straw and corncob for ethanol production using $S$. cereviceae [37] could shorten the process by 24 hours and get the same level of substrate conversion. However, the application of SSF for xylitol has not been thoroughly investigated.

The challenge in implementing SSF is to obtain the optimum operating conditions, such as: $\mathrm{pH}$ and temperature of both the hydrolysis and fermentation processes, to achieve the optimal yield and productivity. Each process is normally performed at different operating conditions.

The goal of this research was to study the application of SSF for xylitol production from OPEFB. The temperature profile of each separated process, hydrolysis and fermentation, was first studied to obtain the optimum operating condition for the SSF configuration. 
The yield of xylitol from OPEFB as well as the processing time of the SSF process configuration was compared with the separated process.

\section{Materials and Methods}

\subsection{OPEFB Biomass Preparation}

Oil palm empty fruit bunches (OPEFB) was collected from Incasi Raya palm oil mill, West Sumatra, Indonesia. OPEFB was washed, sundried, and mechanically milled to obtain maximum OPEFB particles size of 60 mesh $(<0.85$ $\mathrm{mm})$. The composition of dried OPEFB was reported as $43-43.47 \%$ cellulose, $22.93-23.67 \%$ hemicellulose, $21.27-22.10 \%$ lignin [38].

\subsection{Enzyme, microorganisms, and media}

The enzyme used was Cellic-Htec2 (Novozymes). DNS method [39] was applied to determine the xylanase activities of the enzyme. The yeast strain used in this study for xylitol fermentation, Debaromyces hansenii ITB CCR85 was obtained from the culture collection of Microbiology and Bioprocess Technology Laboratory of Chemical Engineering, Institut Teknologi Bandung. The yeast was maintained in an agar slant consisting of $20 \mathrm{~g} / \mathrm{L}$ bacto-agar, $10 \mathrm{~g} / \mathrm{L}$ peptone-water, $5 \mathrm{~g} / \mathrm{L}$ yeast extract and $10 \mathrm{~g} / \mathrm{L}$ glucose.
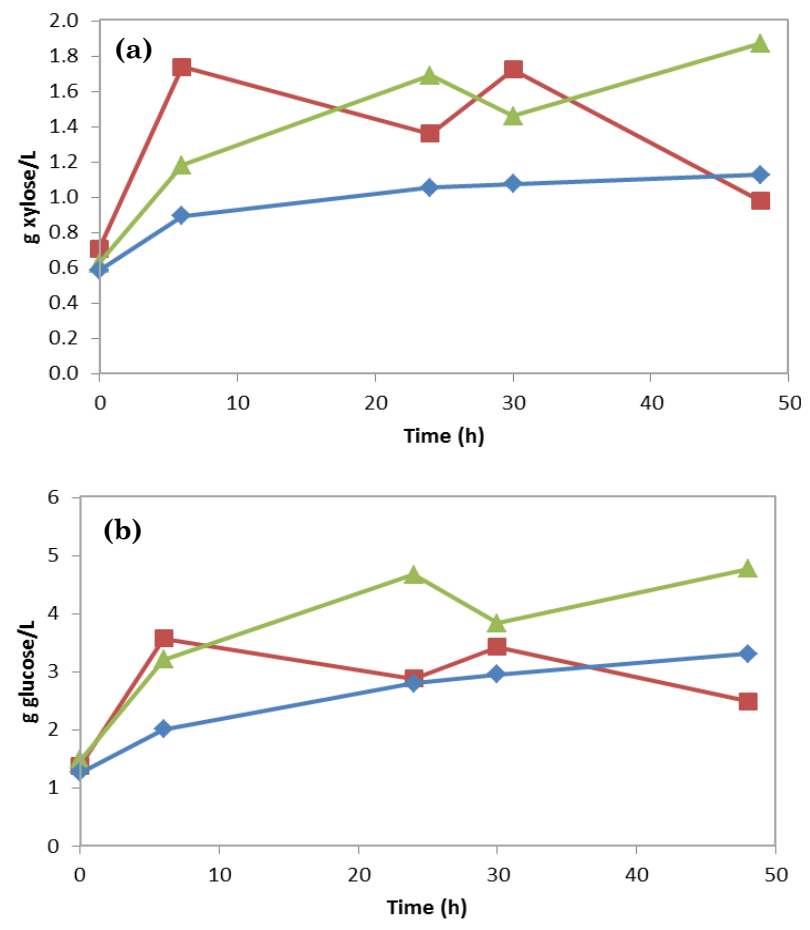

Figure 1. Effects of temperature on OPEFB hydrolysis by crude xylanase (a) xylose, (b) glucose, $\left(30^{\circ} \mathrm{C}(\bullet), 37{ }^{\circ} \mathrm{C}(\boldsymbol{\bullet})\right.$ and $\left.42{ }^{\circ} \mathrm{C}(\boldsymbol{\Delta})\right)$.

\subsection{Hydrolysis and Fermentation of EFB}

Hydrolysis experiment was performed by submerging $10 \mathrm{~g}$ of OPEFB in $200 \mathrm{~mL} 50 \mathrm{mM}$ citrate buffer at $\mathrm{pH} 5.2$, giving a solid loading of $5 \%(\mathrm{w} / \mathrm{v})$. This solution was steam sterilised at 1 barg for 15 minutes before the enzyme was added to the system. Total xylanase activity of $1180 \mathrm{U} / \mathrm{mL}$ medium was applied in every experiment. The experiment was conducted at 30 , 37 , and $42{ }^{\circ} \mathrm{C}$ in the orbital shaker at $150 \mathrm{rpm}$. A synthetic medium containing $20 \mathrm{~g} / \mathrm{L}$ xylose and inorganic salts solution [40] was used in the separated fermentation experiments. Fermentation was conducted at various temperatures, such as 30,35 , or $37^{\circ} \mathrm{C}$, in a shaker incubator at $150 \mathrm{rpm}$.

Simultaneous Saccharification and Fermentation (SSF) experiments were carried out at the previously obtained optimal temperature for hydrolysis and fermentation, by varying the hydrolysis and fermentation time. After the designed time was set for the prior hydrolysis, $D$. hansenii inoculum solution and inorganic salts solution were added to the hydrolysate for starting the fermentation. As a control, a similar experiment set up was conducted with 72 hours of hydrolysis, followed by separation of hydrolysate from OPEFB residue. The fermentation was conducted using the only hydrolysate without the OPEFB residue. Samples were taken periodically for biomass, sugars, and metabolic products analysis.

\subsection{Analytical Methods}

Biomass cell concentration was quantified by counting cell numbers under a microscope using a haemocytometer counter (NEUBAUER, Tiefe $0.100 \mathrm{~mm}, 0.0025 \mathrm{~mm}^{2}$, SUPERIOR W-Germany). Sugar concentration: glucose and xylose, and the metabolic product concentration: xylitol and ethanol were analysed by using a Waters High-Performance Liquid Chromatography system using an organic acid column (Aminex HPX87H Ion Exclusion Column, Biorad) and Refractive Index Detector. $\mathrm{H}_{2} \mathrm{SO}_{4}$ was applied as the eluent at a flowrate of $0.6 \mathrm{~mL} / \mathrm{min}$ at a column temperature of $60^{\circ} \mathrm{C}$.

\section{Results and Discussion}

3.1 Effects of Temperature on OPEFB Hydrolysis Process by crude xylanase

The enzymatic hydrolysis of OPEFB by crude xylanase was evaluated at $30-42^{\circ} \mathrm{C}$. The obtained results are presented in Figure 1. The 
temperature certainly affected the performance of enzymatic hydrolysis. An increase in temperature increased the sugar recovery. After 48 hours of hydrolysis, an increase in hydrolysis temperature from 30 to $37{ }^{\circ} \mathrm{C}$ increased the obtained xylose concentration in the OPEFB hydrolysate from $1 \mathrm{~g} / \mathrm{L}$ to $1.5 \mathrm{~g} / \mathrm{L}$.

Further increased from 37 to $42^{\circ} \mathrm{C}$ gave no significant increase in xylose recovery. On the other hand, an increase in temperature from 30 to $37^{\circ} \mathrm{C}$ did not increase the glucose recovery significantly. The significant increase was only observed when the hydrolysis temperature was set at $42{ }^{\circ} \mathrm{C}$.

Overall, the obtained results suggest that the greater conversion in hydrolysis would be achieved at a higher temperature at the shorter period and that $42{ }^{\circ} \mathrm{C}$ is the favourable condi-
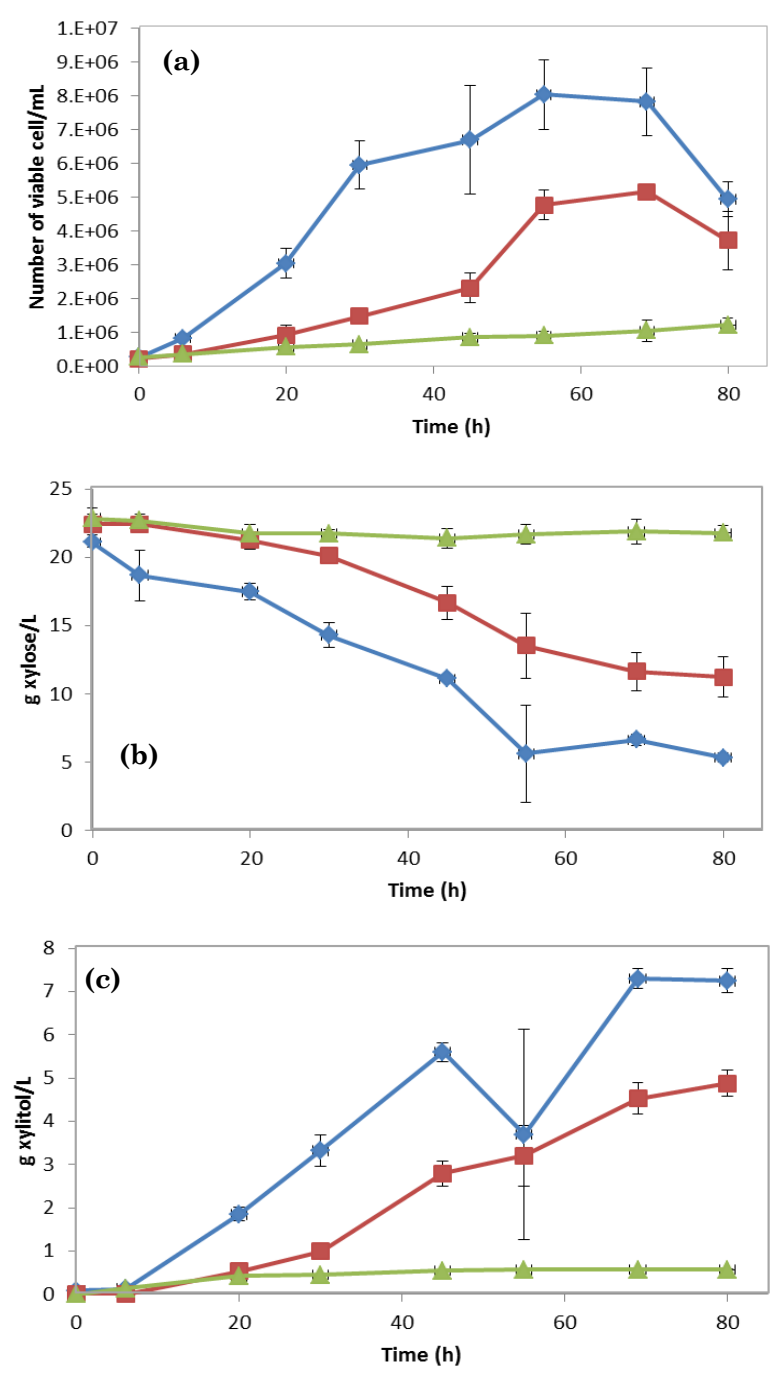

Figure 2. Effects of temperature on xylose fermentation; the time profiles of biomass concentration (a), xylose and xylitol concentration (b) $\left(30^{\circ} \mathrm{C}(\diamond), 35{ }^{\circ} \mathrm{C}(\boldsymbol{\bullet})\right.$ and $\left.37^{\circ} \mathrm{C}(\boldsymbol{\Delta})\right)$ tion to obtain better sugar recovery [41,42].

3.2 Effects of Temperature on Xylose Fermentation by $D$. hansenii

Effect of temperature also was investigated in xylose fermentation using $D$. hansenii (Figure 2). The optimal temperature for the highest xylitol production and cell growth was observed at $30{ }^{\circ} \mathrm{C}$. The xylitol concentration after $69 \mathrm{~h}$ fermentation was measured to be 7.3 $\mathrm{g} / \mathrm{L}$, giving the yield of xylitol on substrate $\left(Y_{p / s}\right)$ were calculated to be $0.47 \mathrm{~g}$-xylitol/gxylose. Whereas the volume productivity and the specific growth rate were calculated to be 0.11 g-xylitol/L/h and $0.19 \mathrm{~h}^{-1}$, respectively. At other evaluated temperatures, 35 and $37{ }^{\circ} \mathrm{C}$, the growth rate and productivity of xylitol dropped significantly, to $0.08-0.03 \mathrm{~h}^{-1}$, and to 0.06-0.07 g xylitol/L/h, respectively. Although the related yield $Y_{p / s}$ remained constant 0.44 $0.53 \mathrm{~g}$ xylitol/g xylose consumed.

The yield obtained in this study was comparable to literatures [43], it was reported that the yield of xylitol from consumed xylose and the xylitol volume productivity of the new isolated D. hansenii (UFV-170) to be $0.54 \mathrm{~g} / \mathrm{g}$ and $0.24 \mathrm{~g} / \mathrm{L} / \mathrm{h}$, respectively after $24 \mathrm{~h}$ incubation at $30{ }^{\circ} \mathrm{C}$. Other literatures also showed that the yield of xylitol at $30{ }^{\circ} \mathrm{C}$ was $0.79 \mathrm{~g} / \mathrm{g}$-xylose, which was obtained within 225 hours [21]; whereas [44] cultivated $D$. hansenii at $30^{\circ} \mathrm{C}$ for $72 \mathrm{~h}$ and obtained yield xylitol about $0.5 \mathrm{~g} / \mathrm{g}$ xylose.

Prakash et al. isolated a new strain of thermotolerant D.hansenii from overripe grapes and used it to produce xylitol from sugarcane bagasse hydrolysate [45] and reported xylitol yield of $0.76 \mathrm{~g}$ xylitol/g xylose consumed or 0.17 $\mathrm{g}$ xylitol/g bagasse with the productivity as much as $0.44 \mathrm{~g} / \mathrm{L} / \mathrm{h}$ at $40{ }^{\circ} \mathrm{C}$. However, the results obtained from this study showed that the optimal temperature for $D$. hansenii ITB CCR85 was $30{ }^{\circ} \mathrm{C}$ with the lower xylitol to $\mathrm{xy}$ lose yield.

\subsection{Evaluation of SSF}

The results on the temperature profile of the OPEFB hydrolysis and the xylose fermentation processes showed that the optimum temperature for each process was $42{ }^{\circ} \mathrm{C}$ and $30{ }^{\circ} \mathrm{C}$, respectively. Accordingly, the prior hydrolysis process was conducted on $42{ }^{\circ} \mathrm{C}$, whereas the SSF was conducted on $30{ }^{\circ} \mathrm{C}$. The SSF was evaluated by varying the time duration for the prior hydrolysis process or in other words by varying the commencement of the SSF (Figure 3). Increase the concentration of sugars: glu- 
cose and xylose were observed during the prior hydrolysis step. Decreasing trends of sugar and consistently increasing trends of xylitol and ethanol were observed following the addition of yeast inoculum, which started the fermentation.

As was expected, the maximum sugar concentration, xylose and glucose, increased when the prior hydrolysis process was prolonged. The maximum xylose concentration was $5.7 \mathrm{~g} / \mathrm{L}, 8.6$ $\mathrm{g} / \mathrm{L}, 8.9 \mathrm{~g} / \mathrm{L}$, and $9.2 \mathrm{~g} / \mathrm{L}$, for the duration of prior hydrolysis $0,24,48$, and 72 hours, respectively. Therefore, the apparent xylose yield from OPEFB increased with the longer duration of prior hydrolysis (Table 1).

The highest yield of xylose from OPEFB was 0.19 g-xylose/g-OPEFB, which was obtained at the duration of prior hydrolysis of 72 hours. Considering hemicellulose content of OPEFB of about 19.1\% [14], the obtained results showed that the hydrolysis yield was 0.88 or that most of hemicellulosic OPEFB have been hydrolysed into xylose. The increase in glucose concentration during hydrolysis was less prominent. The glucose concentration only increased slightly from its initial concentration, 10.2-12.4 g/L.

Not all available sugar was consumed during the fermentation period. Only at experiments of SSF without prior hydrolysis and SSF after 48 hours of hydrolysis, most of the available xylose was consumed. The utilisation of glucose in all SSF experiments was lower than $100 \%$ as well.

The consumed xylose was converted into xylitol. However, at low xylose concentration, the produced xylitol can be consumed by the cell, as shown in Figure 3a-c. The highest xylitol production was observed at SSF after 72 hours of hydrolysis, giving a maximum xylitol concentration of $3.9 \mathrm{~g} / \mathrm{L}$ (Figure $3 \mathrm{~d}$ ).

The consumed glucose was converted into ethanol. Interestingly, the later the SSF was started, the lower ethanol concentration was produced. Indeed, the later the SSF was commenced provided a higher ratio of xylose to glucose concentration for the fermentation, thus in favour of xylitol production. This is in agreement with the previous observation that indicated that there was an optimum ratio of $\mathrm{xy}$ lose to glucose concentration that was preferred for optimum xylitol production [31]. Glucose was only needed at a certain proportion to support cell growth. The remaining glucose would be converted into ethanol. Overall, the results showed that the SSF configuration could provide a condition that favours xylitol production and less ethanol production. Comparison of various SSF configurations is summarised in Table 1.
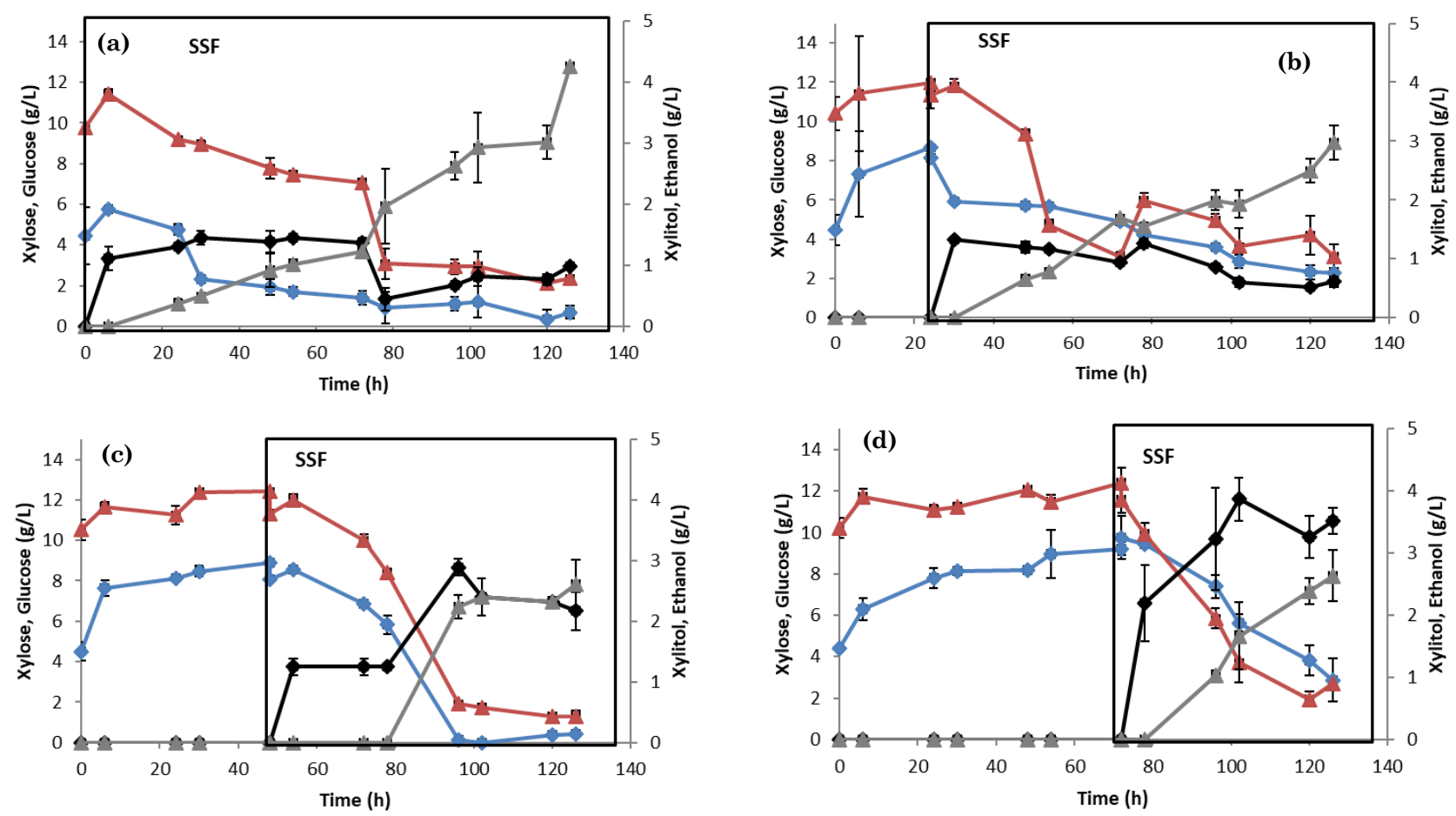

Figure 3. The profile of xylose $(\bullet)$, glucose $(\boldsymbol{\Delta})$, xylitol $(\bullet)$ and ethanol $(\boldsymbol{\Delta})$ concentrations corresponding to variation in configuration times of hydrolysis and SSF; SSF was performed (a) from the beginning, (b) after $24 \mathrm{~h}$, (c) after $48 \mathrm{~h}$ and (d) after $72 \mathrm{~h}$. 
The separated hydrolysis and fermentation experiment, in which the OPEFB hydrolysis was conducted for 72 hours and the fermentation was conducted using only the hydrolysate or without the OPEFB residue, was also conducted at the control experiment and the results are presented in Figure 4.

The separated hydrolysis and fermentation was shown to give comparable ethanol concentration but lower xylitol concentration. The SSF configuration was observed to give higher apparent xylose utilisation than the separated configuration, 0.70 versus 0.67 , respectively. The SSF configuration was also observed to give higher apparent xylitol to xylose yield than the separated configuration, 0.56 versus $0.19 \mathrm{~g}$-xylitol/g-xylose, respectively.

Simultaneous saccharification and fermentation configuration for xylitol production, in particular by utilising $D$. hansenii is barely reported in literature. The obtained results were comparable with the literature [29] which utilized D. hansenii NRRL Y-7426 to produce xylitol from acid-treated detoxified filtrated EFB hydrolysate. The yield xylitol to xylose con- sumed obtained were $0.5 \mathrm{~g} / \mathrm{g}$ and $0.6 \mathrm{~g} / \mathrm{g}$, respectively for fermentation using raw hydrolyzate and charcoal treated hydrolyzate after $200 \mathrm{~h}$ fermentation at $30{ }^{\circ} \mathrm{C}$. The obtained result showed a higher xylitol to xylose yield than the previous one [31], in which the same strain of $D$. hansenii was used and gave xylitol yield of $0.24 \mathrm{~g} / \mathrm{g}$-xylose.

Several investigations showing the higher xylitol yield used substrates i.e. cashew apple bagasse, corncob, sago trunk, sorghum straw which have xylose to glucose mass ratio much greater than unity. It was also reported that the xylose in higher concentration favours more xylitol produced by yeasts [46-48]. The hydrolysate obtained in this study contained more glucose than xylose. Moreover, the maximum xylose concentration was only in the order of $10 \mathrm{~g} / \mathrm{L}$. These need to be solved to obtain higher yield and concentration of xylitol produced.
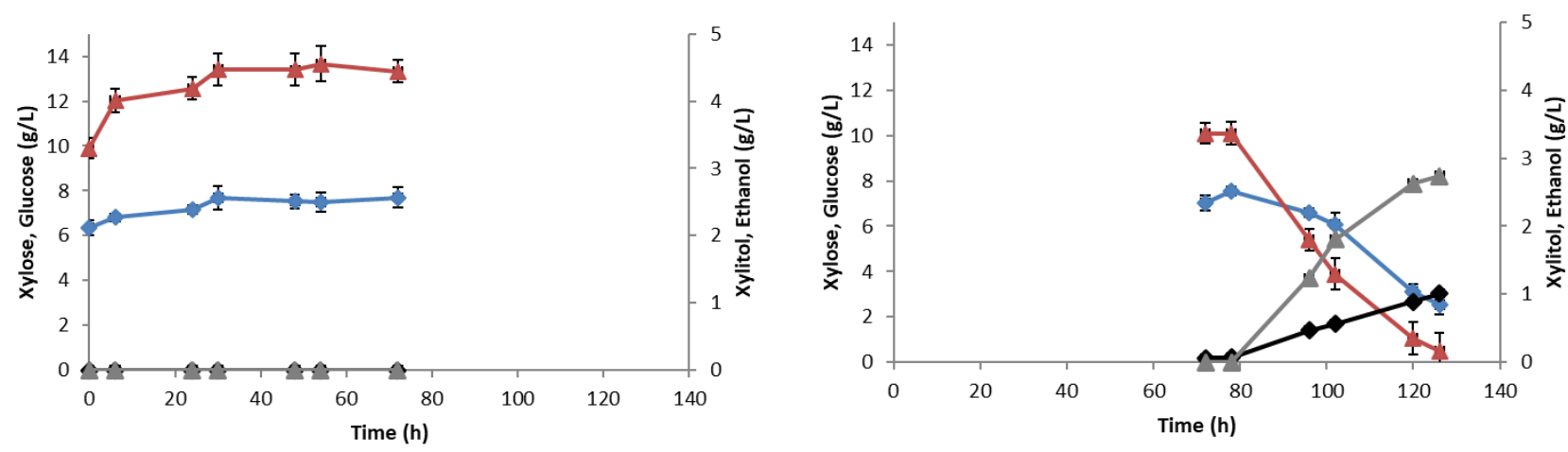

Figure 4. The profile of xylose $(\diamond)$, glucose $(\boldsymbol{\Delta})$, xylitol $(\diamond)$ and ethanol $(\boldsymbol{\Delta})$ concentrations at separate hydrolysis and fermentation experiment, hydrolysis was conducted for $72 \mathrm{~h}$ whereas fermentation was conducted using only OPEFB hydrolysate as media.

Table 1. Evaluation of various SSF configurations

\begin{tabular}{lcccc}
\hline $\begin{array}{c}\text { Hydrolysis and fermenta- } \\
\text { tion configuration }\end{array}$ & $\begin{array}{c}\text { Apparent yield of } \\
\text { xylose* } \\
\text { [g-xylose/ } \\
\text { g-OPEFB] }\end{array}$ & $\begin{array}{c}\text { Apparent yield of } \\
\text { glucose* } \\
\text { [g-glucose/ } \\
\text { g-OPEFB] }\end{array}$ & $\begin{array}{c}\text { Yield of xylitol** } \\
\text { [g-xylitol/ } \\
\text { g-OPEFB] }\end{array}$ & $\begin{array}{c}\text { Yield of ethanol } \\
\text { [g-ethanol/ } \\
\text { g-OPEFB] }\end{array}$ \\
\hline SSF at t $=0 \mathrm{~h}$ & 0.11 & 0.23 & 0.03 & 0.09 \\
SSF at $=24 \mathrm{~h}$ & 0.17 & 0.24 & 0.03 & 0.06 \\
SSF at t $=48 \mathrm{~h}$ & 0.18 & 0.25 & 0.06 & 0.05 \\
SSF at t $=72 \mathrm{~h}$ & 0.19 & 0.25 & 0.08 & 0.05 \\
separate hydrolysis and & 0.15 & 0.27 & 0.02 & 0.05 \\
fermentation & & 0.27 & 0.05 \\
\hline
\end{tabular}

* calculated as the ratio of apparent maximum concentration of xylose/glucose in the broth to the concentration of OPEFB used in the beginning of the experiment

** calculated as the ratio of maximum concentration of xylitol/ethanol in the broth to the concentration of OPEFB used in the beginning of the experiment 


\section{Conclusions}

Simultaneous saccharification and fermentation of OPEFB for xylitol production provided higher performance than separated hydrolysis and fermentation processes. The optimum SSF configuration was obtained at 72 hours prior to OPEFB hydrolysis at $42{ }^{\circ} \mathrm{C}$ and $\mathrm{SSF}$ at $30{ }^{\circ} \mathrm{C}$ for the remaining time frame of 140 hours. This configuration gave the yield of xylitol from OPEFB of $0.08 \mathrm{~g}$-xylitol/g-OPEFB.

\section{Acknowledgements}

Authors would like to thank Aria Ajidharma, Rizkia Kunti Pragati, and Fadian Farisan Silmi for some experimental works. This research was funded by Indonesian Fund Management Board of Oil Palm Plantation (BPDP Sawit).

\section{References}

[1] Kresnowati, M., Mardawati, E., Setiadi, T. (2015). Production of Xylitol from Oil Palm Empty Friuts Bunch: A Case Study on Bioefinery Concept. Modern Applied Science, 9(7): 206-213.

[2] Mohamad, N.L., Kamal, S.M.M., Mokhtar, M.N. (2014). Xylitol Biological Production: A Review of Recent Studies. Food Reviews International, 31: 74-89.

[3] Chen, X., Jiang, Z.-H., Chen, S., Qin, W. (2010). Microbial and Bioconversion Production of D-xylitol and Its Detection and Application. International Journal of Biological Sciences, 6(7): 834-844.

[4] Parajo, J.C., Dominguez, H., Dominguez, J.M. (1998). Biotechnological Production of Xylitol. Part 1: Interest of Xylitol and Fundamentals of Its Biosynthesis. Bioresources Technology, 65: 191-201.

[5] Badiei, M., Asim, N., Jahim, J.M., Sopian, K. (2014). Comparison of Chemical Pretreatment Methods for Cellulosic Biomass. APCBEE Procedia, 9: 170 - 174.

[6] Jiang, L., Zheng, A., Zhao, Z., He, F., Li, H., Wu, N. (2016). The comparison of obtaining fermentable sugars from cellulose by enzymatic hydrolysis and fast pyrolysis. Bioresource Technology, 200: 8-13.

[7] Loow, Y.-L., Wu, T.Y., Jahim, J.M., Mohammad, A.W., Teoh, W.H. (2016). Typical conversion of lignocellulosic biomass into reducing sugars using dilute acid hydrolysis and alkaline pretreatment. Cellulose, 23: 1491-1520.

[8] Kumar, S., Dheeran, P., Singh, S.P., Mishra, I.M., Adhikari, D.K. (2015). Bioprocessing of bagasse hydrolysate for ethanol and xylitol production using thermotolerant yeast. Bioprocess and Biosystems Engineering, 38(1): 39-47.

[9] Dalli, S.S., Patel, M., Rakshit, S.K. (2017). Development and evaluation of poplar hemicellulose prehydrolysateupstream processes for the enhanced fermentative production ofxylitol. Biomass and Bioenergy, 105: 402410.

[10] Fehér, A., Fehér, C., Rozbach, M., Barta, Z. (2017). Combined Approaches to Xylose Production from Corn Stover by Dilute Acid Hydrolysis. Chem. Biochem. Eng. Q, 31(1): 7787.

[11] Ibrahim, M.M., El-Zawawy, W.K., AbdelFattah, Y.R., Soliman, N.A., Agblevor, F.A. (2011). Comparison of alkaline pulping with steam explosion for glucose production from rice straw. Carbohydrate Polymers, 83(2): 720-726.

[12] Bali, G., Meng, X., Deneff, J.I., Sun, Q., Ragauskas, A.J. (2014). The Effect of Alkaline Pretreatment Methods on Cellulose Structure and Accessibility. ChemSusChem, 00: 1-5.

[13] Falls, M., Holtzapple, M.T. (2011). Oxidative Lime Pretreatment of Alamo Switchgrass. Applied Biochemistry and Biotechnology, 165(2): 506-522.

[14] Harahap, B.M., Kresnowati, M. (2018). Moderate pretreatment of oil palm empty fruit bunches for optimal production of xylitol via enzymatic hydrolysis and fermentation. Biomass Conversion and Biorefinery, 8(2): 255263.

[15] Buzała, K.P., Kalinowska, H., Małachowska, E., Przybysz, P. (2017). Conversion of various types of lignocellulosic biomass to fermentable sugars using kraft pulping and enzymatic hydrolysis. Wood Science and Technology, 51(4): 873-885.

[16] Martı'n-Sampedro, R., Eugenio, M.E., Garcı'a, J.C., Lopez, F., Villar, J.C., Diaz, M.J. (2012). Steam explosion and enzymatic pre-treatments as an approach to improve the enzymatic hydrolysis of Eucalyptus globulus. Biomass and Bioenergy, 42: 97-106.

[17] Yadav, M., Mishra, D.K., Hwang, J.-S. (2012). Catalytic hydrogenation of xylose to xylitol using ruthenium catalyst on $\mathrm{NiO}$ modified $\mathrm{TiO}_{2}$ support. Applied Catalysis A: General, 425-426: 110-116.

[18] Pham, T.N., Samikannu, A., Rautio, A.-R., Juhasz, K.L., Konya, Z., Warna, J., Kordas, K., Mikkola, J.-P. (2016). Catalytic Hydrogenation of D-Xylose Over Ru Decorated Carbon Foam Catalyst in a SpinChem(R) Rotating Bed Reactor. Topics in Catalysis, 59(1314): 1165-1177. 
[19] Nigam, P., Singh, D. (1995). Processes for Fermentative Production of Xylitol - a Sugar Substitute. Process Biochemistry, 30(2): 117124.

[20] Mardawati, E., Andoyo, R., Syukra, K.A., Kresnowati, M., Bindar, Y. (2017). Production of xylitol from corn cob hydrolysate through acid and enzymatic hydrolysis by yeast. IOP Conf. Series: Earth and Environmental Science, 141: 1-11.

[21] Parajo, J.C., Domi'nguez, H., Domi'nguez, J.M. (1996). Xylitol from wood: study of some operational strategies. Food Chemistry, 57(4): 531-535.

[22] Wen, X., Sidhu, S., Horemans, S.K.C., Sooksawat, N., Harner, N.K., Bajwa, P.K., Yuan, Z., Lee, H. (2016). Exceptional hexosefermenting ability of the xylitol-producing yeast Candida guilliermondii FTI 20037. Journal of Bioscience and Bioengineering, 121(6): 631-637.

[23] Hernández-Pérez, A.F., Costa, I.A.L., Silva, D.D.V., Dussán, K.J., Villela, T.R., Canettieri, E.V., Jr., J.A.C., Neto, T.G.S., Felipe, M.G.A. (2016). Biochemical conversion of sugarcane straw hemicellulosic hydrolyzate supplemented with co-substrates for xylitol production. Bioresources Technology, 200: 1085-1088.

[24] Winkelhausen, E., Kuzmanova, S. (1998). Review: Microbial Conversion of D-Xylose to Xylitol. Journal of Fermentation and Bioengineering, 86(1): 1-14.

[25] Tamburini, E., Costa, S., Marchetti, M.G., Pedrini, P. (2015). Optimized Production of Xylitol from Xylose Using a Hyper-Acidophilic Candida tropicalis. Biomolecules, 5: 19791989.

[26] Sampaio, F.b.C., Mantovani, H.r.C., Passos, F.J.V., Moraes, C.l.A.d., Converti, A., Passos, F.v.M.L. (2005). Bioconversion of D-xylose to xylitol by Debaryomyces hansenii UFV-170: Product formation versus growth. Process Biochemistry, 40: 3600-3606.

[27] BPS-Statistics Indonesia. (2015). Statistik Kelapa Sawit Indonesia (Indonesia Oil Palm Statistics) 1978-9947, 5504003: 69-80.

[28] Sung, C.T.B., Joo, G.K., Kamarudin, K.N. (2010). Physical Changes to Oil Palm Empty Fruit Bunches (EFB) and EFB Mat (Ecomat) during Their Decomposition in the Field. Pertanika J. Trop. Agric. Sci., 33(1)(1): 39-44.

[29] Rahman, S.H.A., Choudhury, J.P., Ahmad, A.L. (2004). Biotechnological production of xylitol from oil palm empty fruit bunch, a lignocellulosic waste. In The 4th Annual Seminar of National Science Fellowship, 619-624. Malaysia.
[30] Mohamad, N.L., Kamal, S.M.M., Gliew, A. (2009). Effects of Temperature and $\mathrm{pH}$ on Xylitol Recovery from Oil Palm Empty Fruit Bunch Hydrolysate by Candida tropicalis. Journal of Applied Sciences, 9(17): 3192-3195.

[31] Mardawati, E., Wira, D.W., Kresnowati, M., Purwadi, R., Setiadi, T. (2014). Microbial Production of Xylitol from Oil Palm Empty Fruit Bunches Hydrolysate:The Effect of Glucose Concentration. Journal of the Japan Institute of Energy, 94: 769-774.

[32] Liu, Z.-H., Chen, H.-Z. (2016). Simultaneous saccharification and co-fermentation for improving the xylose utilization of steam exploded corn stover at high solid loading. Bioresources Technology, 201: 15-26.

[33] Kádár, Z., Szengyel, Z., Réczey, K. (2004). Simultaneous saccharification and fermentation (SSF) of industrial wastes for the production of ethanol. Industrial Crops and Products, 20: 103-110.

[34] Saxena, A., Garg, S.K., Verma, J. (1992). Simultaneous Saccharification and Fermentation of Waste Newspaper to Ethanol. Bioresources Technology, 42: 13-15.

[35] Krishna, S.H., Prasanthi, K., Chowdary, G.V., Ayyanna, C. (1998). Simultaneous saccharification and fermentation of pretreated sugar cane leaves to ethanol. Process Biochemistry, 33(8): 825-830.

[36] Saha, B.C., Nichols, N.N., Qureshi, N., Cotta, M.A. (2011). Comparison of separate hydrolysis and fermentation and simultaneous saccharification and fermentation processes for ethanol production from wheat straw by recombinant Escherichia coli strain FBR5. Appl Microbiol Biotechnol, 92: 865-874.

[37] Vintilă, T., Vintilă, D., Neo, S., Tulcan, C., Hadaruga, N. (2011). Simultaneous hydrolysis and fermentation of lignocellulose versus separated hydrolysis and fermentation for ethanol production. Romanian Biotechnological Letters, 16(1): 106-112.

[38] Mardawati, E., Werner, A., Bley, T., Kresnowati, M., Setiadi, T. (2014). The Enzymatic Hydrolysis of Oil Palm Empty Fruit Bunches to Xylose. Journal of the Japan Institute of Energy, 93: 973-978.

[39] Bailey, M.J., Biely, P., Poutanen, K. (1992). Interlaboratory testing of methods for assay of xylanase activity. Journal of Biotechnology, 23: 257-271.

[40] Kresnowati, M., Ardina, A., Oetomo, V. (2012). From Palm Oil Waste to Valuable Products: Microbial Production of Xylitol. In 19th Regional Symposium of Chemical Engineering, Indonesia, Bali. 
[41] Leustean, I., Georgesu, L., Bahrim, G. (2010). Preliminary Study For Optimization of Enzymatic Hydrolysis of Waste Cellulosic Materials. The Annals of the University Dunarea de Jos of Galati Fascicle VI - Food Technology, 35(1): 27-33.

[42] Fenila, F. and Shastri, Y. (2016). Optimal control of enzymatic hydrolysis of lignocellulosic biomass. Resource-Efficient Technologies, 2: S96-S104.

[43] Sampaio, F.b.C., Chaves-Alves, V.n.M., Converti, A., Passos, F.v.M.L., Coelho, J.L.C. (2008). Influence of cultivation conditions on xylose-to-xylitol bioconversion by a new isolate of Debaryomyces hansenii. Bioresources Technology, 99: 502-508.

[44] Carvalheiro, F., Duarte, L.C., Lopes, S., Parajó, J.C., Pereira, H., G'irio, F.M. (2005). Evaluation of the detoxification of brewery's spent grain hydrolysate for xylitol production by $D e$ baryomyces hansenii CCMI 941. Process Biochemistry, 40: 1215-1223.
[45] Prakash, G., Varma, A.J., Prabhune, A., Shouche, Y., Rao, M. (2011). Microbial production of xylitol from D-xylose and sugarcane bagasse hemicellulose using newly isolated thermotolerant yeast Debaryomyces hansenii. Bioresources Technology, 102: 33043308 .

[46] de Albuquerque, T.L., Gomes, S.D.L., Marques Jr., J.E., daSilva Jr., I.J., Rocha,M.V.P. (2015). Xylitol production from cashew apple bagasse by Kluyveromyces marxianus CCA510. Catalysis Today, 255: 33-40.

[47] Kamal, S.M.M., Mohamad, N.L., Abdullah, A.G.L., Abdullah, N. (2011). Detoxification of sago trunk hydrolysate using activated charcoal for xylitol production. Procedia Food Science, 1: 908-913.

[48] Misra, S., Raghuwanshi, S., Saxena, R.K. (2013). Evaluation of corncob hemicellulosic hydrolysate for xylitol production by adapted strain of Candida tropicalis. Carbohydrate Polymers, 92: 1596-1601. 